P-ISSN : 2715-744X

\title{
NILAI PENDIDIKAN KARAKTER DALAM CERITA RAKYAT KABUPATEN BANTUL "KI AGENG MANGIR" (KAJIAN FOLKLOR)
}

Oleh

Riswanda Himawan

Program Studi Pendidikan Bahasa dan Sastra Indonesia, Fakultas Keguruan dan Ilmu Pendidikan Universitas Ahmad Dahlan, Yogyakarta

Riswanda1700003043@webmail.uad.ac.id

DOI:

\begin{tabular}{|l|l|}
\hline Article Info & \multicolumn{1}{c}{ ABSTRACT } \\
Article history: & $\begin{array}{l}\text { The problem in this study is how the structure of the folklore "Ki Ageng } \\
\text { Mangir", the function of folklore from Bantul district "Ki Ageng Mangir", } \\
\text { as well as any moral values contained in the folklore. This study aims } \\
\text { to describe the structure, function and the moral value of the folklore } \\
\text { "Ki Ageng Mangir" The research method used is descriptive, data } \\
\text { collection techniques using reading and note-taking techniques, the } \\
\text { data generated in this study are written data.The results of the study } \\
\text { indicate that the Ki Ageng Mangir people's stories have a function as } \\
\text { the source of reference for historical events in Bantul district, the } \\
\text { values contained in this story are cultural, religious and moral values. }\end{array}$
\end{tabular}

Keywords: Function, Moral Tilapia, Folklore, Ki Ageng Mangir.

\section{ABSTRAK}

Permasalahan dalam penelitian ini adalah bagaimana struktur dari cerita rakyat "Ki Ageng Mangir", fungsi dari cerita rakyat asal kabupaten Bantul "Ki Ageng Mangir", serta nilai moral apa saja yang terdapat dalam cerita rakyat tersebut. Penelitian ini bertujuan untuk mendeskripsikan struktur, fungsi dan nilai moral dari cerita rakyat "Ki Ageng Mangir" Metode penelitian dalam penelitian yang digunakan adalah deskriptif, teknik pengumpulan data menggunakan teknik baca dan catat, data yang dihasilkan dalam penelitian ini adalah data tertulis. Hasil penelitian menunjukkan bahwa ceita rakyat Ki Ageng Mangir memiliki fungsi sebagai sumber refrensi adanya peristiwa sejarah di kabupaten Bantul, nilai yang terdapat dalam cerita ini adalah nilai budaya, religius dan moral.

Kata kunci: Fungsi, Nilai Moral, Cerita Rakyat, Ki Ageng Mangir. 


\section{PENDAHULUAN}

Sastra lisan merupakan bagian yang memiliki posisi dan peranan sangat penting di masyarakat, selain hal tersebut, sastra lisan juga memiliki banyak fungsi yang menjadikan sastra lisan tersebut sangat menarik untuk diteliti oleh para ahli dalam rangka melaksanakan kegiatan pembanguna dan pengembangan bangsa Danandjaja (dalam Kethy Inriani, 2017). Cerita rakyat merupakan kisahan anaonim yang tidak terpacu, terikat dan terkait oleh ruang dan waktu yang tersebar secara lisan di khalayak masyarakat. Cerita rakyat sendiri dapat diartikan sebagai cerita pendek mengenai orang-orang atau suku bangsa yang kelestariannya dijaga secara turun-temurun, yang memiliki manfaat sebagi pedoman kehidupan dalam berbagai bidang, dan biasanya disampaikan secara lisan dari mulut ke mulut Sumardjo dan Saini (dalam Kethy Inriani, 2017)

Pada era revolusi seperti yang terjadi saat ini, kebaradaan sastra lisan terlebih cerita rakyat sudah jarang ditemui, cerita rakyat sudah hampir ditinggalkan bahkan dilupakan, oleh karena itu sangat diperlukan penggalian secara mendalam dan insentif terhadap sastra lisan terlebih cerita rakyat (Syuhada, et.al, 2018) Cerita rakyat "Ki Ageng Mangir" merupakan cerita rakyat yang berasal dari Kabupaten Bantul, Daerah Istimewa Yogyakarta, cerita rakyat tersebut sudah jarang diperdengarkan bahkan hanya sedikit masyarakat saja yang mengetahui mengenai cerita rakyat tersebut.

Cerita rakyat merupakan bagian dari floklor, floklor dapat didefinisikan sebagai sebagian kebudayaan suatu kolektif, yang disebarkan dan diwariskan secara turun- temurun, secara tradisional, baik dalam bentuk lisan maupun disertai dengan gerak isyarat atau alat yang digunakan sebagai pembantu dalam menginggat (Robert Sibarani, 2013)

Folklor lisan merupakan floklor yang berbentuk lisan (murni lisan), yang termasuk ke dalam floklor lisan diantaranya; (1) bahasa rakyat, (2) ungkapan tradisional, (3) pertanyaan seperti halnya teka-teki, (4) puisi rakyat (5) cerita rakyat seperti mite, legenda, dongeng (6) kidung, tembang, ataupun nyanyian rakyat (Yusida Gloriani, 2013)

Segala jenis folklor baik itu yang berbentuk lisan maupun berbentuk lisan, maupun sebagian lisan, ataupun floklor bukan lisan sama-sama memiliki fungsi yang sangat berguna dan bermanfaat bagi kehidupan manusia. Folklor memiliki empat fungsi yakni (a) sebagai system proyeksi (proyective system) bahwasannya floklor difungsikan sebagai cerminan angan-angan suatu kolektif, (b) sebagai alat pengesahan pranata dan lembaga kebudayaan, (c) sebagai alat dalam hal pendidikan (pedagogical device), (d) sebagai alat pengawas, agar peraturan, norma-norma yang berlaku dalam suatu masyarakat dapat dipatuhi.

Selain itu, cerita rakyat yang disampaikan secara lisan memiliki fungsi; (a) fungsi estetis, (2) fungsi etis, (3) fungsi pragmatis dan (4) fungsi historis. Cerita rakyat sebagai warisan budaya bangsa, berfungsi juga memberikan sarana, saranasarana tersebut adalah sarana hiburan, menjadi tanda adanya perjuangan pada tempat tersebut baik pendirian wilayah maupun sebagainya Fatmawati (dalam Siti Hijiriah, 2017) 
Folklor dalam hal ini cerita rakyat merupakan bagian dari sastra daerah yang mempunyai nilai. Nilai sendiri dapat diartikan sebagai fenomena psikis manusia yang menganggap suatu hal sangat bermanfaat dan dalam kehidupannya, sehingga seseorang dapat terlibat langsung baik itu secara fisik maupun mentalanya terhadap fenomena itu, jenis-jenis nilai adalah sebagai berikut; (1) nilai moral, (2) nilai religius, (3) nilai ekonomi, (4) nilai estetika, (5) nilai psikologis. Namun, nilai dalam lingkup suatu kebudayaan dapat dipertimbangkan sebagi hal yang sangat umum dalam konteks pendidikan karakter, nilai-nilai tersebut adalah; (1) nilai budaya, (2) nilai religius dan (4) nilai moral.

Nilai budaya dalam cerita rakyat dapat diartikan sebagai konsep dasar mengenai masalah yang sifatnya umum, nilai budaya sangat bermanfaat dan dirasa sangat penting bagi kehidupan masyarakat. Nilai budaya dapat dijadikan sebagai acuan atau tolok ukur suatu masyarakat dalam berkehidupan, nilai budaya akan bersifat abadi, dan tidak dapat diganikan oleh nilai budaya lainnya, nilai budaya merupakan nilai-nilai yang disepakati, dan tertanam oleh masyarakat suatu daerah tertentu, yang mengakar dengan simbol-simbol suatu masyarakat tertentu, nilai budaya dapat berupa nilai gotong royong, musyawarah, setia kawan, harga diri, tertib dan sabagainya, nilai budaya pada dasarnya digambarkan dalam aktivitas kehidupan sehari-hari Setiadi (dalam Yusida Glorani, 2013).

Nilai religius dapat didefinisikan sebagai nilai yang terkait dengan keagamaan, nilai religius merupakan hal yang paling penting bagi setiap manusia yang sifatnya ketuhanan dan kerohanian. Nilai religius juga dapat diartikan sebagai nilai yang mendidik manusia agar selalu meningkatkan kebaikan dalam konteks hubungannya dengan ketuhanan dan krohanian (Nur Aminah, 2016) Nilai religius sendiri dapat berupa (1) kayakinan, (2) peribadatan, (3) penghayatan, (4) pengetahuan dan (5) pengalaman Thontoni (dalam Nur Aminah, 2016)

Nilai moral sendiri memiliki penegrtian sebagai tata nilai, baik buruknya, suatu kegiatan, perbuatan, tingkah laku berkaitan dengan apa yang harus dihindari, dan apa yang harus dikerjakan, sehingga tercipat sebuah rangkaian hubungan manusia dalam masyarakat yang dianggap baik, serta bermanfaat bagi seseorang tersebut. Nilai moral dapat diambil sebagai tauladan dalam berkehidupan, hal baik apa yang dapat dicontoh dalam cerita, dan hal buruk apa yang harus dihindari dari cerita. Beberapa hal yang terkait dengan nilai moral baik dapat berupa; (a) Sabar, (b) taat beribadah, (c) penolong, (d) dermawan, (e) suka menolong, sedangkan moral buruk dapat digambarkan dari kegiatan seperti; (a) berbohong, (b) intrik, (c) konflik Wicaksono (dalam Nur Aminah, 2016)

Berkaitan dengan kajian atau penelitian mengenai Fungsi dan nilai dalam cerita rakyat, penelitian yang relevan dan lebih dahulu dilakukan oleh Syuhada, Akhmad Murtadlo, Alfian Rokhmansyah (2018) dengan penelitiannya yang berjudul "Nilai Dalam Cerita Rakyat Suku Dayak Tunjung Tulur Aji Jangkat Di Kutai Barat: Kajian Folklor”. Persamaan penelitian ini dengan penelitian yang akan peneliti lakukan yakni sama-sama mengkaji mengenai nilai yang ada dalam cerita rakyat, hal yang membedakan terletak pada cerita rakyat yang 
dikaji, penelitian yang dilakukan oleh Syuhada dkk meneliti mengenai cerita rakyat "Suku Dayak Tunjung Tulur Aji Jangkat”, sedangkan penelitian yang akan dilakukan peneliti dalam penelitian ini mengkaji mengenai cerita rakyat "Ki Ageng Mangir" yang berasal dari Kabupaten Bantul, Daerah Istimewa Yogyakarta. Penelitian kedua yang relevan dan lebih dahulu dilakukan oleh Siti Hijiriah (2017) dengan penelitiannya yang berjudul "Kajian Strutur, Fungsi Dan Nilai Moral Dalam Cerita Rakyat Sebagai Bahan Ajar Pembelajaran Apresiasi Sastra" persamaan penelitian yang dilakuakn oleh Siti hijiriah dengan penelitian yang akan dilakukan oleh peneliti yaitu sama-sama meneliti mengenai Fungsi yang terkandung dalam cerita rakyat, hal yang membedakan yaitu jika penelitian yang dilakukan oleh Siti hijiriah meneliti fungsi dan nilai moral, namun penelitian yang akan dilakukan oleh peneliti meneliti fungsi dan nilai cerita rakyat secara luas. Ketiga, penelitian yang relevan dan lebih dahulu dilakukan oleh Tjetjep Rosmana (2010) dengan penelitiannya yang berjudul Mitos Dan Nilai Dalam Cerita Rakyat Masyarakat Lampung, penelitian ini sama-sama meneliti mengenai nilai yang terdapat dalam cerita rakyat, bedanya penelitian yang dilakukan Tjetjep Rosman meneliti juga mengenai mitos, sedangkan penelitian yang akan dilakukan oleh peneliti dalam peneliti ini tidak meneliti mengenai mitos yang terdapat dalam cerita rakyat.

Berdasarkan uraian yang telah disampaikan, penelitian mengenai Kajian Fungsi Dan nilai Dalam Cerita Rakyat " $K i$ Ageng Mangir" sangat diperlukan, selain digunakan sebagai sumber refrensi dan pengetahuan, penelitian ini juga berfungsi untuk mengetahui fungsi apakah yang terdapat dalam cerita rakyat " $\mathrm{Ki}$ Ageng Mangir" serta nilai apa saja yang terdapat dalam cerita rakyat "Ki Ageng Mangir"

\section{METODE PENELITIAN}

Penelitian ini menggunakan metode deskriptif kualitatif, yakni prosedur yang mengandung dan menghasilkan data secara tertulis mengenai "Fungsi dan Nilai Dalam Cerita Rakyat "Ki Ageng Mangir" dalam penelitian kualitatif, menghasilkan dan menggunakan data utama berupa kata-kata Endraswara (dalam Purwanto, 2010) Objek dari penelitian ini adalah cerita rakyat " $\mathrm{Ki}$ Ageng Mangir" yang diadopsi secara daring (Online) Teknik pengumpulan data dalam penelitian ini adalah teknik baca dan teknik catat, sedangkan teknik analisis data yang dilakukan yakni dengan pembacaan cerita, penandaan kajian, pencatatan data, mengkalsifikasikan data, setelah data-data terkumpul data disesuaikan dan dianalisis kembali, melalui pendapat ahli dan beberapa hasil penelitian yang relevan dan lebih dahulu dilakukan. Penelitian ini tidak hanya berhenti pada proses analisis data, namun nantinya data yang terkumpul akan disimpulkan.

Teori yang digunakan sebagai landasan dalam penelitian ini adalah teori pragmatik Abrams, pendekatan pragmatik sendiri memberikan perhatian secara utama, pendekatan pragmatik memberikan perhatian, fungsi, dan manfaat bagi para pembaca (Abrams,1976) Manfaat kajian ini bagi para pemvaca yakni sebagai refrensi, dan pengetahuan mengenai fungsi, nilai yang terkandung dalam cerita rakyat "Ki Ageng Mangir". Alasan penulis memilih cerita rakayat tersebut karena cerita rakyat tersebut 
memiliki nilai kekhasan tersendiri, tokoh $\mathrm{Ki}$ Ageng Mangir sangat dikenal oleh masyarakat bantul, karena pada dasarnya desa yang menjadi latar terjadinya cerita masih ada dan dilestarikan oleh masayarakat Bantul, desa tersebut bernama desa Mangir, kecamatan Pajangan, Kabupaten Bantul.

\section{PEMBAHASAN}

\section{a. Fungsi Cerita}

Berdasarkan hasil analisis, cerita rakyat "Ki Ageng Mangir" memiliki fungsi sebagai sarana sumber pengetahun dan juga pendidikan, di mana cerita rakyat " $\mathrm{Ki}$ Ageng Mangir" ini dapat dimanfaatkan sebagai alat untuk mengetahui bahwasannya peranah terjadi peristiwa bersejarah di wilayah Kabupaten Bantul, khususnya di kecamatan Pajangan. Selain itu, cerita rakyat ini juga dapat digunakan sebagai sumber bukti munculnya desa "Mangir" yang terletak di kecamatan Pajangan tersebut, di mana desa Mangir merupakan tempat tinggal "Ki Ageng Mangir" di kala sedang berjuang melawan penjajahan, hal ini dibuktikan pada bait akhir cerita, berikut kutipan ceritannya "Bagaimana pun Ki Ageng Mangir sebagai menantu sekaligus musuh Panembahan Senopati, untuk mengenang Ki Ageng Mangir, maka tempat tinggal Ki Ageng Mangir dinamakan Desa Mangir yang terletak di kecamatan Pajangan, Kabupaten Bantul, Daerah Istimewa Yogyakarta”

Kedua, cerita rakyat ini dijadikan sebagai sarana sistem proyeksi (proyective system) bahwasannya cerita rakyat "Ki Ageng Mangir" difungsikan sebagai cerminan angan-angan suatu kolektif, mengenai kehidupan di masyarakat, kedamaian serta memaksa masyarakat untuk selalu mencintai, mematuhi nasihat isteri demi harmonisnya hubungan keluarga atau rumah tangga, hal ini dibuktikan dengan kutipan cerita sebagai berikut "Demi cintanya terhadap sang istri dan sang jabang bayi yang dikandung pembayun, Ki Ageng Mangir mau menuruti permintaan isterinya untuk menghadap Panembahan Senopati ke Mataram" Kutipan cerita tersebut, membuktikan bahwa $\mathrm{Ki}$ Ageng Mangir sangat mencintai Pembayun sebagai Isterinya, sehingga Ia mau menuruti permintaan isterinya yang meminta agar $\mathrm{Ki}$ Ageng Mangir mau datang dan menemui Panembahan Senopati, walaupun Panembahan Senopati merupakan musuh dan juga mertua dari Ki Ageng Mangir. Hal ini menjadikan contoh bahwasannya cerita ini memaksa masyarakat sebagai pembaca untuk selalu mencintai isteri dan anak demi terciptanya hubungan harmonis dalam suatu rumah tangga. Ketiga, cerita rakyat ini juga dapat difungsikan sebagai sarana pendidikan, sebagai refrensi belajar, karena nilai keteladanannya dapat digunakan sebagai refrensi untuk mawas diri, dalam berkehidupan. Pendapat ini sejalan dengan pendapat Robert Sibarani (2013) yang menyatakan bahwasannya folklor berfungsi sebagai alat dalam hal pendidikan (pedagogical device) salah satunya sebagai refrensi dalam pembelajaran moral.

\section{Nilai dalam Cerita}

Berdasarkan hasil analisis terdapat beberapa nilai yang ada dalam cerita rakyat "Ki Ageng Mangir" nilai-nilai tersebut adalah nilai (1) budaya, (2) religius, (3) moral, berikut penjelasan beberapa nilai dalam cerita rakyat "Ki Ageng Mangir":

\section{a. Nilai Budaya}


Telah dijelasakan sebelumnya bahwasnnya nilai budaya dalam cerita rakyat dapat diartikan sebagai konsep dasar mengenai masalah yang sifatnya umum, nilai budaya sangat bermanfaat dan dirasa sangat penting bagi kehidupan masyarakat. Nilai budaya juga didefinisikan sebagai pedoman tertinggi bagi masyarakat dalam suatu daerah beberapa nilai budaya yang terdapat dalam cerita rakyat "Ki Ageng Mangir" adalah sebagai berikut; (1) budaya musyawarah, nilai ketertiban dalam cerita tersebut dibuktikan dengan kutipan "Panembahan Senopati mengadakan musyawarah di kerajaan Mataram agar Mataram mempersiapkan untuk melakukan perlawanan terhadap Ki Ageng Mangir, akan tetapi, Ki Juru Mertani penasihat Kerajaan Mataram tidak setuu apabila Ki Ageng Mangir dihadapi dengan perang, sebab akan membawa banyak korban. Nasihat dari ki Juru Mertani dipertimbangkan oleh Panembahan Senopati" dari kutipan tersebut, dapat diketahui bahwasannya sang Raja Pnembahan Senopati dalam memutuskan sebuah keputusan dilandasi dengan etika musyawarah, hal ini membuktikan bahwa merumuskan pendapat melalui musyawarah merupakan suatu perilaku atau kegiatan yang dinilai sangat baik dalam pengambilan keputusan, sehingga keputusan yang diambil tidak hanya bersumber dari satu orang saja, melainkan hasil pemikiran dari beberapa pikiran. Musyawarah menurut KBBI (2015) dapat diartikan sebagai pembahasan bersama, dengan maksud pengambilan keputusan atas suatu masalah. Musyawarah dalam cerita ini dapat dijadikan nilai pedoman bagi para pembaca, agar dalam setiap pengambilan keputusan yang berkaitan dengan banyak orang, dilakukan secara kebersamaan dengan melibatkan anggota dalam suatu kelompok.

Nilai budaya yang kedua adalah nilai gotong royong, hal ini dibuktikan dari kutipan cerita yang dapat disajikan sebagai berikut "Pembayun ditemani oleh saudara dan penggiringnyam pembayun menjadi ledhek dan saudara menjadi penabuh gamelan, mereka kemudian ngamen berkeliling kampung" Kutipan cerita tersebut menggambarkan nilai gotong royong, gotonmg royong yang dimaksud adalah pembayun dalam mematuhi permintaan atau perintah sang Ayah dibantu oleh saudarsaudaranya dan juga penggiringnya, pembayun yang menari ledhek sedangkan saudara dan penggiringnya yang menjadi penabuh gamelan. Hal ini membuktikan bahwasannya nilai budaya gotong royong antar keluarga sangat ditekankan di sini, di sisi lain cerita rakayat ini juga memaksa masyarakat untuk selalu gotong royong dalam setiap keadaan, karena gotong royon akan meringankan pekerjaan dan juga dapat mencapai tujuan secara maksimal, cerita ini memberikan nilai terhadap masyarakat pembaca akan pentingnya gotong royong dengan dibuktikan perilaku kehidupan para tokoh sehari-hari, masyarakat dapat mencontoh kehidupan para tokoh sebagai refrensi dalam menjalani kehidupan bermasyarakat di lingkungan sekitarnya.

\section{b. Nilai Religius}

Cerita Rakyat "Ki Ageng Mangir" mengandung nilai religius, yang didasarkan oleh keajaiban tokoh, kemujijatan dari suatu tokoh yang merupakan mujizat yang diberikan oleh tuhan yang maha esa oleh setiap makhluknya. Kemujizatan yang ditemukan dalam cerita ini yaitu 
bahwasannya sang raja "Ki Ageng Mangir" diceritakan sebagai raja yang sakti mandraguna, hal ini dibuktikan dengan kutipan cerita sebagai berikut "Ki Ageng Mangir adalah seorang penguasa tanah Mangir, Ia dikenal sebagai pemimpin yang gagah, tampan, berani, dan sakti mandraguna". Sakti mandra guna dalam cerita tersebut dimaksudkan bahwasannya $\mathrm{Ki}$ Ageng Mangir memiliki mukjizat yang luar biasa, Ia dikenal sebagai seseorang yang dikarunia atau memiliki senjata ampuh berupa tombak yang dinamakan Baru Klinthing, senjata tersebut merupkan tombak yang berasal lidah seekor ular naga, raksasa yang bernama baru klinthing. Peristiwaperistiwa tersebut termasuk ke dalam nilai religius yang berupa kemukjizatan mengenai kejadian atau peristiwa yang menyimpang dan keluar dari hukum alam, hanya sebagian orang saja yang mendapatkan mukjizat tersebut, mukjizat juga dapat didefiniskan sebagai peristiwa yang sukar dijangkau oleh kemampuan akal manusia (KBBI, V)

\section{c. Nilai Moral}

Nilai moral dalam cerita rakyat " $\mathrm{Ki}$ Ageng Mangir" ditemukan melalui atau didasarkan dari perkataan, dan perbuatan yang dilakukan oleh tokoh peristiwa pertama dapat dilihat dari kutiapn cerita berikut ini "Panembahan Senopati kemudian memanggil puterinya, yaitu puteri pembayun, Panembahan Senopati merencanakan untuk menaklukkan Ki Ageng Mangir melalui puterinya, Pembayun pun diutus untuk menjadi ledhek, putri pembayun pun menyanggupi permintaan ayah nya" hal ini membuktikan bahawasannya pembayun sangat hormat dan patuh terhadap orang tuanya, terlebih ayahnya. Nilai moral untuk patuh dan hormat terhadap orang tua yang terdapat dalam cerita ini dapat dijadikan sebagai pedoman hidup masyarakat pembaca, hal ini sesuai dengan pendapat Wicaksono (dalam Nur Aminah, 2016) yang berpendapat bahwa Nilai moral dapat diambil sebagai tauladan dalam berkehidupan, hal baik apa yang dapat dicontoh dalam cerita, dan hal buruk apa yang harus dihindari dari cerita. Nilai moral untuk hormat dan patuh terhadap orang tua dalam cerita tersebut merupakan nilai moral yang termasuk ke dalam nilai moral baik. Nilai moral baik yang kedua adalah sabar, hal ini dibuktikan dalam kutipan caerita "Pembayun tetap dengan sabar meredam kemarahan Ki Ageng Mangir, yang marah terhadap Ayahnya" sabar dalam kutipan caerita tersebut dapat dijadikan sebagai contoh nilai moral yang baik bagi para pembaca,dan diterapkan dalam kehidupan sehari-hari.

Nilai moral yang didefinisikan sebagai tata nilai, baik buruknya, suatu kegiatan, perbuatan, tingkah laku berkaitan dengan apa yang harus dihindari, dan apa yang harus dikerjakan, sehingga tercipat sebuah rangkaian hubungan manusia dalam masyarakat yang dianggap baik, serta bermanfaat bagi seseorang tersebut. Di samping nilai baik dalam cerita, terdapat juga nilai buruk yang harus dihindari oleh masyarakat pembaca dalam berkehidupan, nilai buruk yang menjadi gambaran untuk dihindari oleh masyarakat dalam berkehidupan dalam cerita tersebut dapat dilihat dari kutipan cerita berikut ini "Akan tetapi Ki Ageng Mangir tetap pada pedniriannya, tidak mau menghadap dan tunduk pada Mataram, Ia menganggap bahwa sanya tanah Mangir adalah tanah perdikan, Ia tidak sudi untuk tunduk terhadap 
tanah Mataram" dari kutipan cerita tersebut, dapat kita lihat bahwasannya Ki Ageng Mangir memiliki watak keras kepala, angkuh dan sombong. Ia tidak mau tunduk terhadap Panembahan Senopati, Ia menganggap bahwasannya tanah Mangir adalah tanah perdikan, perdikan merupakan daerah yang dibebaskan membayar pajak pada pemerintah, pemrintah yang di maksud adalah pemerintahan pada masa penjajahan Belanda (KBBI, V) watak yang dimiliki oleh Ki Ageng Mangir tersebut termasuk ke dalam watak buruk, di mana watak buruk tersebut dimaksudkan agar dihindari dan tidak dilakukan oleh masyarakat pembaca, karena akan memberikan dampak yang tidak baik bagi dirinya, maupun orang lain.

\section{KESIMPULAN}

Berdasarkan hasil analisis, terkait dengan analisis fungsi dan nilai yang terdapat dalam cerita rakyat " $\mathrm{Ki}$ Ageng Mangir" ditemukan beberapa hasil analisis atau hasil penelitian sebagai berikut; (1) cerita rakyat Ki Ageng Mangir memiliki fungsi sebagai bujti bahwasannya pernah terjadi peristiwa kesejarahan di kabupaten Bantul, khusunya di Kecamatan Pajangan, (2) cerita rakyat ini dijadikan sebagai sarana sistem proyeksi (proyective system) bahwasannya cerita rakyat "Ki Ageng Mangir" difungsikan sebagai cerminan angan-angan suatu kolektif, mengenai kehidupan di masyarakat, kedamaian serta memaksa masyarakat untuk selalu mencintai, mematuhi nasihat isteri demi harmonisnya hubungan keluarga atau rumah tangga, (3) cerita rakyat ini juga dapat difungsikan sebagai sarana pendidikan, sebagai refrensi belajar, karena nilai keteladanannya dapat digunakan sebagai refrensi untuk mawas diri, dalam berkehifupan. Berdasarkan analisis nilai ditemukan beberapa nilai yakni nilai; (1) Budaya terletak pada budaya musyawarah yang sering dilakukan di wilayah Kerajaan, (2) nilai religius, terkait kesaktian atau mukjizat yang dimiliki oleh seseorang, di luar batas kemampuan manusia atau menyimpang dari akal pikiran alam, (3) nilai moral, moral baik dalam cerita dicontohkan dalam perilaku spatuh kepada orang tua, sabar, sedangkan nilai moral buruk yang harus dijauhi adalah nilai angkuh, sombong dan keras kepala yang ditunjukkan oleh perilaku tokoh.

\section{DAFTAR PUSTAKA}

Danandjaja, J. (2002). Folklor Indonesia, Ilmu Gosip, Dongeng, dan Lain-lain. Jakarta: Pustaka Utama Grafiti.

Endraswara, S. (2008). Metode Penelitian Folklor. Yogyakarta: Media Pressindo.

Fatmawati A. (2015). Tradisi Lisan Bersesombau Melayu Tapung (Fungsi, Keterkaitan dengan Perilaku Masyarakat dan Program Revitalisasi. (Rangkuman Disertasi). Universitas Pendidikan Indonesia Bandung.

Hijiriah, S. (2017). Kajian Struktur, Fungsi, Dan Nilai Moral Cerita Rakyat Sebagai Bahan Pembelajaran Apresiasi Sastra. Jurnal Riksa Bahasa, 3(1), 117-125.

Kamus Besar Bahasa Indonesia (KBBI) edisi V. (http://kbbi.web.id/diakses pada 23 Juli 2020 pukul 20.00 WIB)

Kethy, I. (2017). Nilai Kearifan Lokal Dalam Legenda Cerita Rakyat Muntok: Sebuah Kajian Pendidikan Karakter. 
Prosiding seminar bahasa dan sastra di Palembang. 167-177.

Nur, A. (2016). Nilai-nilai Pendidikan Cerita Rakyat Dalam Buku Sastra Lisan Lampung Karya A. Effendi Sanusi Dan Implikasinya Dalam Pembelajaran Bahasa Lampung Di Sekolah Menengah Pertama. Skripsi. Universitas Negeri Lampung.

Rosmana, T. (2010). Mitos Dan Nilai Dalam Cerita Rakyat Masyarakat Lampung. Jurnal Patanjala, 2(2), 191-206.

Sibarani, R. (2013). Folklor Nusantara: Hakikat, Bentuk dan Fungsi. Yogyakarta: Ombak.

Sumardjo, J. \& Saini K.M. (1991). Apresiasi Kesusastraan. Jakarta: PT Gramedia.

Syuhada, A. M., Rokhmansyah, A. (2018). Nilai Dalam Cerita Rakyat Suku Dayak Tunjung Tulur Aji Jangkat Di Kutai Barat: Kajian Folklor. Jurnal Ilmu Budaya, 2(2), 188-195.

Teeuw. A. (1984). Sastra dan Ilmu Sastra Pengantar Teori Sastra. Bandung: Pustaka Jaya.

Wicaksono, A. (2014). Teori Pengkajian Prosa Fiksi. Garudhawaca.

Yusida, G. (2013). Kajian Nilai-Nilai Sosial Dan Budaya Pada Kakawihan Kaulinan Barudak Lembur Serta Implementasinya Dalam Pembelajaran Bahasa dan Sastra Indonesia Berbasis Multikultular. Jurnal Lokabasa, 4(2), 195-208.

https://ceritarakyatnusantara.com (Cerita Rakyat Ki Ageng Mangir/ diakses pada 22/07/2020 pukul $13.00 \mathrm{wib)}$ 